\title{
Ampulla of Vater Cancer pTX TNM Finding v7
}

National Cancer Institute

\section{Source}

National Cancer Institute. Ampulla of Vater Cancer pTX TNM Finding V7. NCI Thesaurus. Code C90267.

Ampulla of Vater cancer in which the primary tumor cannot be assessed. (from AJCC 7th Ed.) 